\title{
A REVIEW OF THE NATURE AND GROWTH OF MULTI-TITLED TOURISM ACCOMMODATION COMPLEXES
}

\author{
Jan WARNKEN, \\ Chris GUILDING \\ and \\ Kelly CASSIDY
}

Service Industry Research Centre

Griffith University - Gold Coast Campus

PMB 50, Gold Coast Mail Centre

QLD 9726

AUSTRALIA

Corresponding author: Chris Guilding

email: C.Guilding@griffith.edu.au

Fax: +61 (0)7 55528507

The authors would like to acknowledge the helpful suggestions provided by two anonymous referees. Financial support for this study has been provided by the Sustainable Tourism CRC. 


\title{
A REVIEW OF THE NATURE AND GROWTH OF MULTI-TITLED TOURISM ACCOMMODATION COMPLEXES
}

\begin{abstract}
The growth of multi-titled tourist accommodation (MTTA) complexes represents a significant addition to our conventional conception of forms of short term accommodation. MTTA complexes are assuming a variety of forms and appear to be proliferating in many parts of the world. This study investigates the international growth of MTTA, with particular emphasis attached to the Australian experience. It also outlines the nature of the new MTTA paradigm, advances a typology of MTTA organisations and identifies the factors accounting for the increased incidence of MTTA.
\end{abstract}

Keywords: Multiple titled tourism accommodation, condominiums, condo-hotels 


\section{A REVIEW OF THE NATURE AND GROWTH OF MULTI-TITLED TOURISM ACCOMMODATION COMPLEXES}

\subsection{Introduction}

As part of a widespread restructuring (Argawal 2002) and diversification (e.g. Priestley and Mundet 1998; Valenzuela 1998; Williams et al. 2000; Argawal 2002, Bramwell, 2004, Aguilo et al. 2005) of the tourism and travel industry, the wellestablished "second home" or "holiday home" construct (Coppock 1977; Hall and Müller 2004) appears to be undergoing a pervasive metamorphosis. The change concerns the rapid increase in tourism accommodation complexes that are sub-divided into separate ownership titles (Pizam, 2006), with complexes frequently comprising as many ownership titles as there are separate units.

Two dimensions of pervasion are manifested in this metamorphosis towards multiple titled tourist accommodation complexes. Firstly, the change is not spatially or institutionally restricted to the traditional "second home" sector, but apparent in many modes of tourism accommodation, e.g., self-service high rise apartment complexes, branded hotels, golf resort communities, villa complexes, and even cruise ships (Weaver 2005). The latter are not considered further herein due to the distinct nature and relatively small size of the cruise ship tourism sector. Secondly, the pervasion is apparent internationally, with considerable growth in multi-titled hotels and selfservice tourism-based apartment complexes evident in many parts of the world (elaborated on below).

Some of the likely factors accounting for the growth in multiple owned tourism accommodation complexes appear to be closely aligned with those recognised to be fuelling growth in "second home" ownership and self-catering stays including, inter alia, greater levels of individual disposable wealth, greater mobile pursuit of leisure activities, more and shorter holidays (Johns and Lynch 2007) and an increasingly aged population seeking seasonal migration to escape extreme summer or winter climates (Irvine and Cunningham 1990, Williams et al. 2000). Other factors relate to property development and marketing issues, e.g., developers' accessing broader markets of potential investors by unitising tourism accommodation ownership (e.g. Nicod et al. 2007 p. 248), and improvements in short-term accommodation marketing available to small operators as a result of new internet-based technology (Thomas and Hind 2007 p.331).

The landscape of multi-title property complexes is extremely diverse and variable. Practically every country, and even region (state, territory or county), has their own rules, regulations, nomenclature and subdivision schemes pertaining to multi-title developments (see Everton-Moore et al. [2006] for an Australian cross-state legislative analysis). Despite this, these schemes exhibit the following three common attributes:

1. They encompass some common property and more than one separate property title linked to the common property or land parcel.

2. They are typically owned by several independent owners.

3. They are subject to local governance administered by an elected committee (e.g., the body corporate committee or community association) according to a 
Defining the sub-set of tourism accommodation complexes that are multi-titled is complicated by the fact that their size, shape, and vertical aspect vary substantially, and terminology suffers from a lack of international standardisation. In the United States they are widely-referred to as 'condominiums', in Australia as 'strata or community titled' complexes, in Germany they are called 'Eigentumswohnungen', in South Africa they are called 'sectional title' complexes, while 'leasehold flats' encompasses most United Kingdom multi-titled tourism accommodation units. A common theme evident across these countries, however, is the establishment of associations representing the specialised businesses that provide administrative and secretarial services to multi-title property complexes, e.g., the National Community Titles Institute in Australia, the National Association of Managing Agents in South Africa, the Association of Residential Managing Agents in the United Kingdom, and the Community Associations Institute in the USA.

In search for common ground, and to separate complexes offering short-term (vacation) accommodation from residential complexes, the term 'multi-titled tourist accommodation' (MTTA) is used to denote any tourist accommodation premises that has a multi-titled, multi-ownership, structure tied to a common property. This definition distinguishes MTTA complexes from the many different forms assumed by traditional holiday homes (Coppock 1977) and also hotels or motels, which are generally built on a single land title that is either leased or owned by a single party.

The definition also distinguishes MTTA from timeshare, because time share investors rarely acquire a property title (Woods 2001). For this reason, timeshare unit management does not fall under the legal jurisdiction governing property and community associations (USA) or strata and community titled complexes (Australia). Further, there is a fundamental difference between MTTA and timeshare properties that is temporally based. An MTTA owner has a continuing right of access, or right to grant access, to their MTTA property for the entire period of their ownership of the asset. An owner of a timeshare property has a right of access, or right to grant access, for only a limited time period in every year (typically one or two weeks) for the duration of their ownership of the asset. Further factors that distinguish the MTTA sector from timeshare and fractionals (Hobson 2002) include:

1. Owners of some MTTA units in a complex can, and frequently do, reside full time in their MTTA. This distinction from timeshare is significant, as a particularly challenging organisational dynamic frequently arises between investor owners and resident owners in MTTAs (see discussion in Guilding et al, 2005).

2. In many MTTAs, ownership of a unit bestows control over the unit's internal refurbishment to the owner (the only exception to this is MTTA type 5 which is introduced later in connection with Table 1). Owner discretionary influence over style and level of refurbishment is absent in timeshare complexes. This signifies a further particular hospitality management challenge arising in many MTTA complexes.

3. Some MTTA owners choose to personally manage the sub-letting of their unit, some put it in the hands of an independent letting agent, while many 
4. It appears that in most countries, timeshare rental income tends to be pooled. This factor has resulted in some countries deeming timeshare ownership to constitute a security investment and not a property investment (Hovey, 2002). In Spanish law, a specific ruling distinguishes timeshare from MTTA (Spanish Law 42/1998). This has resulted in much tighter restrictions being imposed on the running of Spanish timeshare properties.

5. Loans for purchasing timeshare units tend to be provided by small lending institutions with a timeshare loan specialisation, with the loan application exclusively focused on the financial profile of the prospective creditor. In the case of MTTA, a standard mortgage arrangement can be struck with any home lending financial institution, with the underlying property title serving as collateral for the loan.

These factors suggest that it is appropriate to view MTTA as a construct that is distinct from timeshare.

Several implications arise from the growth of MTTA. For academics involved in hospitality management education, it should be apparent that the absence of any reference to MTTA in the curricula represents a glaring irregularity. MTTA presents some particular operational and management issues such as the challenge of inconsistent levels of unit refurbishment, room pricing issues (Cassidy and Guilding, 2007) and the potential of tension between tourists and resident owners. These distinct management issues would appear to warrant recognition in hospitality management education syllabi. Also, Warnken et al. (2003) note several implications arising from an increased incidence of MTTA for destination management. Amongst the issues addressed is a concern that as many MTTA complexes contain tourists and resident owners, a protracted downturn in tourism demand might result in investor owners letting out to long term tenants or selling to resident owners. This could change the profile of the way that MTTA complexes are used, and if a destination is dominated by MTTA, a protracted tourism demand downturn may change the destination's profile.

The pervasive growth of MTTA highlights a significant need for further light to be shed on the nature and context of MTTA. The objectives of this paper are to:

1) Outline the nature of the new MTTA paradigm.

2) Advance a typology of MTTA organisations.

3) Document the growth of MTTA in Australia and provide a generic commentary on the growth of MTTA complexes internationally.

4) Identify and discuss the forces driving MTTA growth.

\subsection{A Typology of MTTA complexes}


When considered in an international context, MTTA complexes can be seen to encompass a broad spectrum of building types ranging from duplex housing (where maybe half of the building is assigned to holiday renting) to large integrated high rise resort complexes that can comprise more than 1,000 apartments (e.g., "condo-hotel" complexes in Las Vegas). In an attempt to capture the main distinctions between the more commonly found MTTA complexes in America, Australasia and Europe, a typology of MTTA complexes has been developed. This typology is depicted in tabular form as Table 1. To facilitate ease of reference, each of the five identified generic MTTA types are enumerated in the Table's first row. The distinctions between the five generic types are based on distinguishing building and operational facets. An underlying pattern of the Table is that MTTA complex size increases as one progresses from type 1 to type 5 . 
Table 1: Common types of MTTA complexes and associated operational arrangements

\section{Type 1 \\ Small \\ Type 2 \\ Medium size, \\ Large, unbranded \\ Type 4 \\ Large size, operated by}

Identifier

characteristics

Low rise apartment, duplex, or

detached villa, etc, complex

comprising 24 units or less.

Usually single storey, but can be up to 3 storeys.

Typical location

Small regional (boutique)

destinations, eg., ski resorts.

Building

maintenance

Volunteer owners or a real estate agent with holiday letting specialisation.

$\begin{array}{ll}\begin{array}{l}\text { Letting } \\ \text { management }\end{array} & \begin{array}{l}\text { Real estate agent or other } \\ \text { specialist letting agencies. }\end{array} \\ \begin{array}{l}\text { Financial } \\ \text { management of } \\ \text { owners } \\ \text { association }\end{array} & \begin{array}{l}\text { Real estate agent or voluntee } \\ \text { resident owner. }\end{array} \\ \begin{array}{l}\text { Typical investor } \\ \text { owner : resident } \\ \text { owner ratio } \\ \begin{array}{l}\text { Short-term } \\ \text { guest reception } \\ \text { facility }\end{array}\end{array} & \begin{array}{l}\text { No formal on-site reception } \\ \text { facility. }\end{array}\end{array}$

unbranded

Medium low rise to small

to $\sim 50$ units; $\geq 3$ to $\sim 10$

storey high rise.

Regional (upcoming

beach) destinations.

Resident owner or

resident manager

contracted by owners' committee.

Real estate agent or

resident manager.

Real estate agent, accountant or specialist community association manager.

Low

Partial on-site reception

facility if letting is

managed by resident

manager. high rise complex; $\geq 24$

destinations, some CBDs.
MTTA specialist

Usually high rise $\geq 8$

storeys, $\geq 50$ units.

Larger regional or major

beach destinations.

Resident manager (often a

husband and wife team) and

maintenance sub-

contractors.

Resident manager.

Accountant or specialis

community association

manager.

Mid-range.

$9-5$ reception facility
Typically high rise,

generally $\geq 60$ units,

typically has about a 3

star rating.

Mostly major beach

MTTA specialist

management company

and maintenance sub-

contractors.

MTTA specialist,

branded, management company.

Accountant in conjunction Accountant in conjunction with MTTA specialist

management company.

with branded hotel group.

High

Highest (approaching

$100 \%)$

24 hours.

24 hours.

60 rooms (often a mix of serviced rooms, dual and

e key apartments),

ently with other

Mostly in CBDs or major

Branded hotel operator.

Branded hotel operator.
Large size operated by

branded hotel chain (condotel)

tourist destinations.

operated by resident

manager. 
MTTA type 1 complexes represent a higher density extension of the traditional "holiday home" sector: they provide accommodation units in low rise buildings, generally without lifts or recreational facilities (e.g., pools, gymnasiums, etc.). Aframes, duplexes, townhouses, villas in upmarket holiday (resort) villages, and small apartment complexes (e.g. ski chalets) constitute examples of MTTA type 1. Construction costs and building safety standard design issues frequently result in the development of apartment complexes in blocks of 6 units. Interior staircases can be used for up to three (sometimes four) storeys with two, four or six apartments frequently found per storey. The four storey and six apartments per storey configuration accounts for 24 units being identified as the upper limit for the type 1 MTTA grouping in Table 1. Typical features of MTTA type 1 complexes include the provision of above ground parking, and ground and building maintenance organised by volunteer owners or a real estate agent. Booking of short-term rentals and subsequent cleaning of units is either handled by the owner, a local tourism bureau or a real estate agency. Unless specific regulations prevent non-local investors from purchasing units in these small complexes (as is the case in parts of Austria), type 1 MTTA complexes can account for a significant proportion of beds in ski or health and spa resorts, e.g., Colorado (USA), Queenstown (New Zealand), Thredbo (Australia), and in parts of northern Europe (e.g. periphery of St Moritz, Switzerland).

Type 2 MTTA complexes have been labelled “Medium size, unbranded”. Complexes characteristic of this grouping are not managed by a professional MTTA operator or branded hotel. They are more common in destinations outside Europe, where tourism accommodation complexes serving the type 2 market sector tend to be dominated by traditional small family hotels and 'pensions' on single titles. In Australia, the majority of these types of MTTA complexes are referred to as "three storey walk-ups" with usually more than 24 units arranged in an "L" or "U" configuration. These complexes typically have several staircases, underground car parking, basic recreation facilities, no conference or meeting facilities, but may have a snack food or small retail outlet located on the ground floor. Many type 2 MTTA complexes can be found in regional tourism seaside destinations (e.g., the Whitsundays or Cairns in Australia), or in the immediate periphery of tourist centres. When the majority of a MTTA type 2's units are placed in a holiday letting pool, bookings and room cleaning tend to be handled by an on-site manager who also oversees ground and building maintenance. In Australia it is common for contracts covering this service provision to be drawn up for 25 years and linked to ownership of a resident manager's unit. This contract is secured by purchasing the 'management rights' which frequently sell for well over a million dollars in large well-appointed complexes that have a high proportion of units in the holiday letting pool (Guilding et al. 2005). The value of management rights derives from letting pool revenue as the management rights holder receives a commission based on rental revenue.

Type 3 MTTA complexes are larger, tending to have more than 50 units (mostly high rise). Some units in these complexes can be occupied by long-term residents (renters and owners) and they are usually sufficiently large to warrant the engagement of a 
full-time resident manager. Type 3 s tend to be located in the periphery of a major tourist attraction or central business district (CBD). A large foyer, underground car parking, large pool and major recreation facilities (spa, gym, tennis court), tend to be standard in type 3 MTTA complexes, and some entertainment facilities suitable for small functions are not uncommon. Older type 3s tend to contain no restaurants or retail units, although the provision of some facilities such as a café appears to be becoming more common in recently constructed complexes built in or near a major tourism hub. Larger, non high rise, complexes that tend to be linked to a major facility such as a golf course or marina can be found in relatively secluded locations in the periphery of major tourism hubs.

Type 4 MTTA complexes can be found in buildings that are very similar to the type 3 complexes, but a key distinguishing feature of the type 4 complex is that it is managed by a specialist MTTA operating company with an established brand name. This branded company generally manages several type 4 MTTA complexes located in or close to major tourism hubs or CBDs. Typical features of a type 4 MTTA complex include a large foyer with a twenty four hour reception facility, a visitor lounge or bar (often providing self service drinks), and seminar facilities equipped with modern communication and display technology. The vast majority of units in the type 4 complexes are in the short-term letting pool, i.e., it will have a low ratio of resident to investor owners.

Type 5 MTTA complexes are operated by branded hotel operators. Based on definitions used in Hawaii (DBEDT, 2005), this category includes most 'condohotels' (sometimes referred to as "condotels" in North America). Apart from some rooms being larger and the occasional provision of some self-catering facilities, most guests would discern no difference between a type 5 MTTA complex and a conventionally owned and managed large hotel. Type 5 MTTA complexes provide a hotel front-end reception staffed with a concierge, full service in-house bar, restaurant and retail facilities, daily room cleaning and service, and are located in the centre of a tourism hub or CBD. Some recently constructed type 5 complexes also provide dual key apartments with small kitchen and laundry facilities that can be separated into units the size of standard hotel rooms. It is evident that many traditional hotels are being reconfigured, and ownership titles sub-divided in order to facilitate conversion into condotels (Smoke and Burk, 2005).

The growth of type 5 MTTA complexes signifies the establishment of a third hotel ownership / management nexus reconfiguration in the last century. In the first half of the twentieth century, the norm for hotel operations was for a hotel company to own and manage hotel properties. Subsequently, from the 1960s onwards (Field, 1995), much hotel development was facilitated by way of a management contract in which a hotel operating company contracted with a hotel owner to manage a hotel complex. This divorce between ownership and responsibility for hotel management is a model that has proliferated internationally (Guilding, 2003), and can be seen as constituting a distinct hotel ownership / management paradigm. It appears that a third hotel ownership / management model is now becoming rapidly established, with the hotel's ownership not being represented by way of a single property title, but by as many property titles (and owners) as there are accommodation units in the complex. This third hotel ownership / management nexus paradigm is likely to place new administrative demands on hotel operators due to the additional burden of maintaining 
working relations with the many independent parties that can represent the hotel's ownership.

\subsection{Growth of MTTA complexes}

The significant growth of MTTA complexes appears to have occurred surreptitiously, with negligible acknowledgement provided by tourism analysts and academics. Most national tourist accommodation accounts or surveys focus on traditional servicerelated categories such as hotels, motels and caravan parks (usually by star-rating), or they combine holiday homes and holiday apartments into one segment. To obfuscate record-keeping matters further, mixed-used complexes with serviced rooms and condominium style apartments have emerged, and these can be variously classified. Agencies managing the compilation of such data sets exhibit little interest in different ownership configurations and frequently fail to capture the subtle difference between a conventionally owned hotel or large motel and a professionally managed MTTA complex. The somewhat blunt nature of tourism accommodation statistics has likely been a significant factor contributing to the lack of recognition afforded to MTTA's increasing significance.

An international search for information concerning MTTA's growth has revealed that Australia provides one of the more detailed data bases. In 1997, the prominence of MTTA complexes in many major Australian destinations prompted the Australian Bureau of Statistics (ABS) to change its accommodation survey categories and recognise 'serviced apartment' complexes with 15 or more units as a distinct letting category. The vast majority of Australian serviced apartments fall under "strata title" legislation, i.e., they are units within MTTA complexes. Prior to 1997, serviced apartment complexes had been included in a broadly defined category described as 'holiday apartments and holiday homes' with more than 4 units per letting entity. The replacement of 4 units per letting entity by 15 units per letting entity as the recording threshold has also applied to hotels and motels. This has resulted in a significant decline in the number of establishments represented in the survey, but only minor changes in the record of room or unit nights sold. Panel A of Figure 1 graphs the ABS guest nights sold per quarter for hotels, motels, and serviced apartments for the period 1998 to mid 2005, and panel B graphs room nights sold for the same accommodation types for the equivalent period. The ABS also provides data for the number of letting entities and takings. Across all these parameters, serviced apartments exhibit the highest growth rates. For example, in the period 1998 to 2004, guest nights sold in Australian hotels with 15 or more rooms increased by $25 \%$, while in serviced apartments with 15 or more rooms, guest nights sold increased by $97 \%$. It is noteworthy that MTTA type 5 complexes are being recorded as hotels under the ABS classification system. This signifies that the relative size of the MTTA sector reflected in Figure 1 is in fact understated. 


\section{Figure 1}

\section{Quarterly tourism accommodation statistics, Australia}

Panel A

Room nights sold

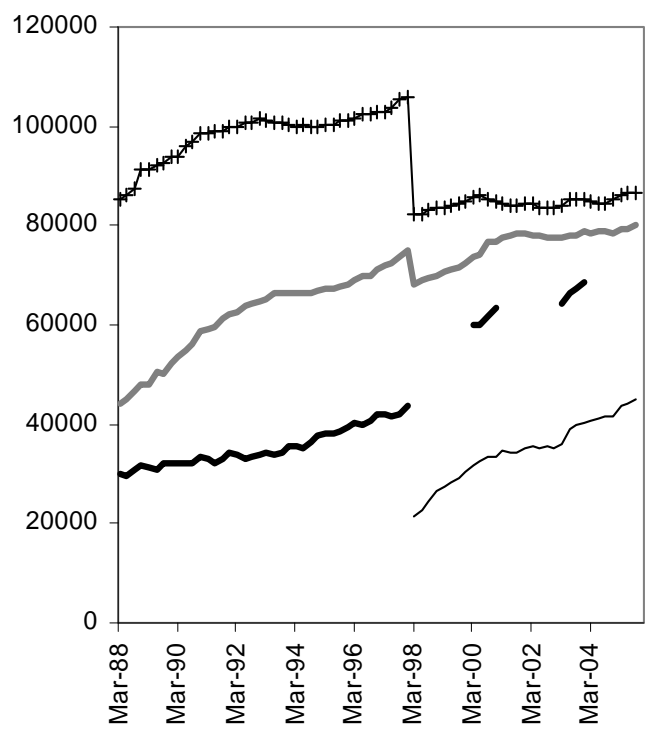

Panel B

Guest nights sold

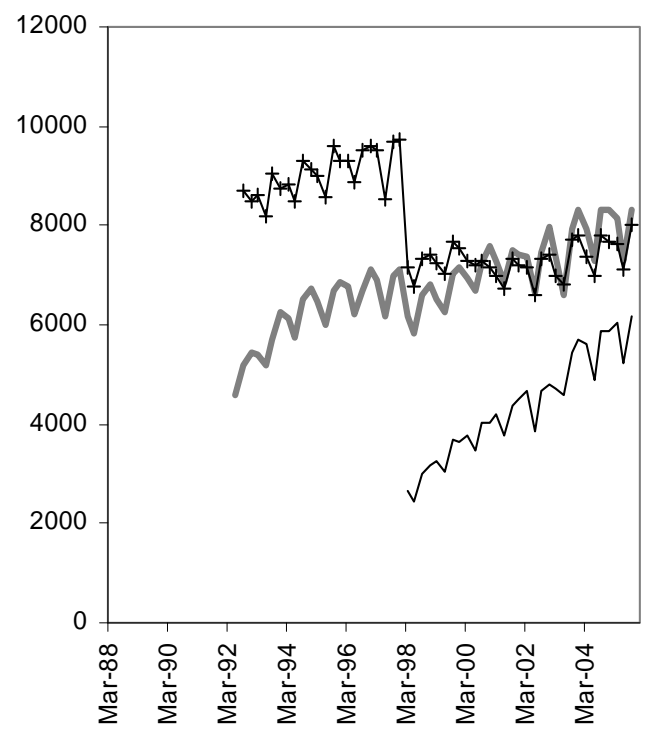

Compiled from Australian Bureau of Statistics (ABS) Tourist Accommodation Survey, Publication Series No. 8635.0, March 1988 - December 2005.

-+-+ = hotels;

= motels;

— $\quad=$ serviced apartments;

— $\quad=$ holiday homes and flats (no guest nights recorded).

Statistics available in Spain, a popular European tourist destination (Williams et al. 2000), typify the problems encountered when attempting to secure robust data concerning MTTA's growth. The Spanish data base generated by the Instituto Nacional de Estadística provides information for a 'hoteles' category (which pools 'apartahoteles' and 'hotel-apartamentos' with conventional hotels), and records 'hostales' and 'apartamentos touristicos' which pools traditional holiday homes with apartments commonly associated with owners' main residence and other non-camping style accommodation units. Based on listings provided by local tourism bureaus on the Internet, it appears that the "hoteles" category includes most MTTA properties, possibly mixed with some timeshare units. This category recorded a growth in guest nights of 16\% during the period 2000 to 2005, while guest nights in 'hostales' and apartementos touristicos' declined by $7 \%$ and 16\%, respectively (Figure 2). Figures from 1996 (cited in Valenzuela, 1998) indicated that $18.5 \%$ of all tourist beds were found in registered apartments, which at that time already dominated tourism 
accommodation in many destinations such as the Islas Canarias (greater than 50\%), Marbella and the Islas Baleares, notably Mallorca. These figures likely represent an underestimation of the actual number of apartments, due to owner resistance to register units that are predominantly used by friends and family (Valenzuela 1998). The introduction of Spanish Law 42/1998 represents an attempt to curb the intertwined proliferation of MTTA and timeshare units by distinguishing between "multipropriedad" and timeshare properties. 
Figure 2

Spanish monthly tourism accommodation statistics

Guest nights ('000)

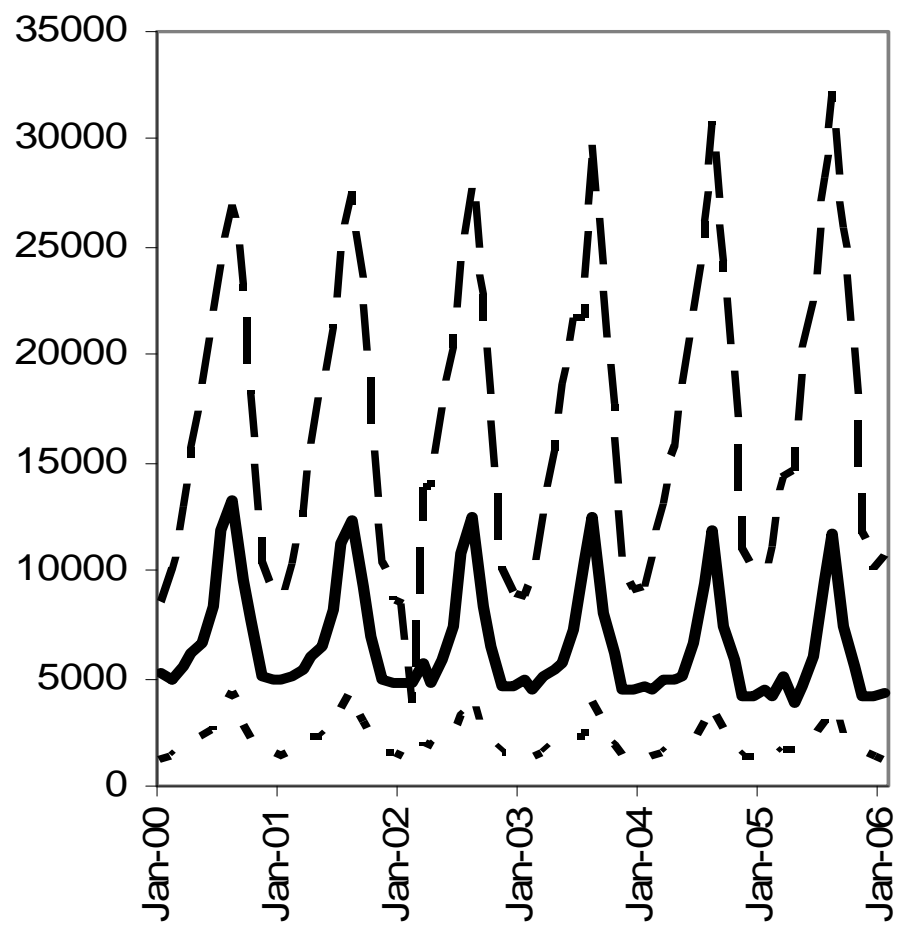

Compiled from Instituto Nacional de Estadística (INE) Tourist Accommodation Survey, electronic data format 2000 - 2005.

- - - : hoteles;

- - : hostales;

- : apartamentos touristicos.

In light of the failure to find reliable statistics concerning MTTA in most countries, an internet search programme was conducted as part of the attempt to further insight. Practically every Internet accommodation search engine for major destinations returned listings with MTTA-style complexes. While it is difficult to corroborate the exact size of MTTA's market penetration, an Internet based investigation provides a very strong impression that MTTA now represent a significant element in tourism accommodation infrastructures internationally. In fact, in several destinations it appeared MTTA complexes dominate the tourist accommodation 'landscape'.

Internet listings viewed in March 2006 for some of Spain's major seaside resorts revealed 217 apartment complexes and 69 'hoteles” listed on Gran Canaria's tourism board website; around 240 apartment complexes and 'hotel apartamentos' compared to 420 'hoteles' in Majorca; and 114 apartment entities compared to 341 hoteles for 
Andalusia. This provides a strong suggestion that, if not MTTA-style per se, then certainly apartment-style accommodation is highly popular in major Spanish destinations. MTTA-style apartment developments also appear to be widespread in French seaside resorts, notably in the Languedoc Roussillon (Klemm 1996). Casual observation also suggests there are many MTTA developments on the French Riveria and Italian Adriatic coasts.

Ascertaining growth rates for MTTA-style complexes in the U.S.A. using published data bases has proven to be impossible, although Internet listings suggest MTTA constitutes a sizable element of the USA's tourism accommodation infrastructure. In March 2006, 61 planned condominium hotel properties were advertised for Florida and another 30 across 13 other states. For Hawaii in 2004, there were 268 condominium entities listed compared to 156 hotels (DBEDT 2005), an increase of $188 \%$ and $30 \%$ respectively, since 1999. Further, several hundred condominium and apartment properties were noted when searching Florida's official tourism website. Pizam (2006) notes that the US condominium hotel sector has grown from US $\$ 160$ million in 1999 to more than US\$1 billion in 2004.

\subsection{Factors accounting for MTTA development}

The apparent international growth of MTTA complexes noted in the previous section beckons the question: what factors are driving this new form of tourism accommodation ownership? Answers to this question will be sought by considering the motivation of several different stakeholders involved in developing, using and operating MTTA complexes.

Large building developers represent an obvious key stakeholder group as they constitute the party playing the pivotally significant role of deciding what type of new tourism accommodation complexes are to be constructed and what ownership structures will be initially established. This pivotal role is underscored when it is recognised that a tourism accommodation building's physical configuration will be planned with due consideration given to the particular operational needs of the intended end-user. Basic decisions made by a developer at the front end of a complex's life are largely irreversible. Once built, the costs of reconfiguring a building in a way to service the needs of a distinctly different end user group will often be prohibitively expensive. Perhaps more significantly, whilst one can conceive of a single owner deciding to convert a complex's ownership structure to a multiple title format five years into a complex's life, it is nigh on impossible to conceive of one hundred owners of a MTTA complex attempting to convert their multiple title configuration into a single title. This signifies that a developer's decision to establish a multi-titled arrangement for a property is likely to be irreversible during the property's life. Having noted the pre-eminent role played by developers in connection with MTTA growth, four factors providing an incentive for developers to build MTTA complexes will now be outlined.

Firstly, a fundamental incentive for developers to build MTTA complexes arises from the fact that units within the complex can be marketed 'off the plan', i.e. before any construction of the building has commenced (Pizam, 2006). The receipt of funds for units sold off the plan reduces financial exposure borne by either the developer or a lending institution during a complex's construction phase. The ability to minimise this 
financial exposure is a key factor attracting developers to the construction of multiowned complexes.

Secondly, many MTTA complexes are not restricted to tourism use, i.e., they include long-term residential as well as short-term rental units (mixed use). Developers are able to secure finance more easily for developments that are seen to have a broad market of purchasers rather than a narrowly defined, tourism-based market. A more broadly defined market signifies easier and quicker access to a developer's clients' (i.e., unit owners) funds. Unlike most commercial settings where a retailer's clients provide operating revenue, a developer's client base provides revenue that is more akin to capital, i.e., it is a revenue source that will enable the developer to draw down loans raised specifically to finance the building of a complex. The easier access to capital achieved by broadening the developer's clientele base not only signifies an ability to secure needed finance, it also facilitates the raising of loan capital with preferential conditions, e.g., a lower interest rate than would apply if a building is a tourism specific construction.

A third incentive for developers to build MTTA complexes in preference to conventional single title tourism accommodation complexes stems from the fact that the MTTA complex represents a vehicle facilitating the equity stakeholding of small investors in large tourism accommodation complexes. A parallel can be drawn between MTTA's expansion and the development of joint stock companies in England between the mid sixteenth and seventeenth centuries (Harris, 2000). A fundamental justification of joint stock companies (i.e., companies owned by way of shares) is that they facilitate the raising of capital. If an expanding economic entity needs to raise significant capital to fund growth and it is not subject to multiownership (by way of shares) then its capital raising options are limited by the wealth of its owner. An economic entity owned by shares, however, has the capacity to seek more equity capital from the whole of the investing community by way of issuing a prospectus that represents a public advertisement for equity funds. Similarly, by breaking up a tourism accommodation complex into units of ownership, a developer can draw on a much broader market for investment capital than if the complex were to be subject to a single ownership title. It is also noteworthy that the growth in MTTA has occurred contemporaneously with considerable growth in individual disposable incomes and wealth.

This broader market for investment capital signifies that a whole new set of factors are brought into play with respect to the investors' motivation and psyche. It appears reasonable to suggest that the advent of more small tourism accommodation investors signifies an increased proportion of unsophisticated investors. Small investors can be expected to be attracted to MTTA unit ownership by a range of factors that can include: the notion of a leisure-oriented life style (or holiday home), the ostentatious motivation of owning a status symbol, the desire to secure a future retirement residence, the desire to diversify a pension investment portfolio, and personal tax planning (in some jurisdictions). The first three of these five factors are not present in a corporation's decision to invest in a tourism accommodation complex, which can be expected to more closely approximate to an investment motivated by economic rationale. This signifies that, as a generalisation, small scale investors are not as focused on investment returns as their large corporate based investing counterparts. 
From a developer's perspective, this signifies a lower premium attached to demonstrating adequate financial returns when marketing to small investors.

A fourth factor motivating developers' engagement in MTTA developments arises from the option provided to retain ownership over selected units, thereby facilitating the pursuit of a potential real estate speculation motive. Also, in some jurisdictions, MTTA development provides the opportunity to sell management rights for the building. This has been referred to as the "icing on the cake" and, as has been already noted, management rights can command considerable values (Guilding et al, 2005).

A second stakeholder group, real estate agents, also appear to profit greatly from MTTA developments. The construction of a MTTA complex creates immediate activity for real estate agents engaged to sell units off the plan. When assigned a large volume of similarly designed contiguous units, a real estate agent can realise significant economies of scale. Once the initial period of sales to new unit owners elapses, it will be replaced by unit resales occurring for the remaining life of the building, with the majority of sales being brokered by real estate agents. In many MTTA complexes (predominantly types 1 and 2), real estate agents will also benefit by acting as letting agents for the unit owners. This on-going activity generated for real estate agents by MTTA complexes is considerable when compared to hotel developments. If a large hotel is sold, the sale is rarely mediated by a real estate agency, it is more likely to be brokered by a specialised investment company; also, a real estate agency does not become involved in the sub-letting of hotel rooms. Recognising real estate agents' interest in MTTA developments, and the ability of real estate agents to reap economies of scale when selling off the plan signifies that real estate agents are likely to offer their services to developers using greatly discounted fee structures.

Tourists represent a further stakeholder group that stands to benefit from increased MTTA. Anecdotal evidence suggests an increase in demand for self catering short holidays (long weekends up to one week) amongst young families and self catering accommodation for increasingly wealthy retirees who wish to escape extreme winter and summer weather conditions (Williams et al. 2000). MTTA types 1, 2 and 3 appear to be particularly well-suited to cater to the needs of the young family market, while the greater affluence of retirees signifies that they are in a position to consider letting any of the five MTTA types, although an extended booking is more likely to be made in a MTTA type 1, 2 or 3. By foregoing the provision of higher service levels (e.g., 24 hours reception facilities), and by increasing the number of users per unit rented, relative to hotels or motels, MTTA type 1, 2 and 3 operators can offer lower per person prices for similarly sized rented areas. The provision of a fully equipped kitchen and laundry facilities, which is commonly required by financiers and building societies of MTTA types 1, 2 and 3, is particularly important to price conscious travellers.

In some ways, host communities may also derive greater benefits from MTTA complexes relative to traditional hotel or motel premises. Most MTTA operators, and in particular those in medium-size and larger buildings, tend to outsource a large number of tasks (landscaping, pool and linen cleaning, window cleaning, etc.) rather than employ their own staff. This provides business opportunities, as opposed to salaried or waged employment, for members of the local community. The distinction 
between the provision of sub-contracted local business opportunities and local employment opportunities is important as the former signifies the retention of MTTA related profits in the local community, while the latter frequently signifies the direction of profits to a non-local party. No evidence revealing whether this factor is viewed to be important by local planning authorities when deciding whether to grant building permission to a planned MTTA complex has been noted.

Finally, information technology advancements appear to be supporting MTTA developments. The growth of the Internet, in particular, has greatly facilitated advertising and room booking management for small tourism accommodation operators. Estate agents can now use the Internet to provide updates on accommodation availability for their pool of letting units that might well be drawn from many different small MTTA complexes. Improved internet search engines are providing greater access to tourists who, in the past, had to rely on wholesaler advertising or word-of-mouth information. Further, the advent of cheaper desktop computer-based booking and financial management systems are enabling many more small tourism accommodation providers to operate relatively sophisticated room management systems. These developments can be expected to have been particularly beneficial for MTTA types 1, 2 and 3.

\subsection{Discussion and conclusions}

It is believed this paper constitutes the first to provide a holistic critique concerned with an apparently burgeoning form of tourism accommodation ownership that bears a sharp parallel to corporations owned by way of shares. Joint stock companies now constitute the predominant form of commercial enterprise in most capitalist economies. Only time will tell if the emergence of jointly owned property complexes will prove to be as profound and enduring.

As this is the first critique concerned with MTTA, it is bound to have a scoping orientation. This scoping characteristic is particularly evident with respect to the MTTA typology provided. The need to provide such a classification scheme is a common trait of new realms of scientific enquiry. Given the social scientific nature of MTTA complexes, however, it should be acknowledged that the typology offered suffers from some slightly blurred demarcations. Despite this, it does represent a useful mechanism for distinguishing between the main types of complex populating the MTTA landscape.

The critique has also attempted to provide some insights into the growth of MTTA internationally. A significant shortcoming of the study is apparent, however, due to the difficulty of acquiring verifiable data concerning MTTA's growth. With the possible exception of Australia, the currently available statistical data bases signify that further enquiries concerned with documenting MTTA's growth might be best served by acquiring primary empirical data. Despite this, Internet searches, anecdotal evidence (eg., Pizam, 2006) and casual observation collectively suggest that MTTA complexes represent an increasingly significant component of the tourism industry in many parts of the world. Regional differences are certainly apparent, however. For instance, in some countries, e.g., the U.S.A. and Canada, interest in MTTA-complex investment appears to be moderated by strong competition from the timeshare sector and a quest for rural retreats which represent a conventional holiday home setting to 
many North Americans, especially those living far from the sea. It appears that when holiday homes are sought in close proximity to the sea, considerable premium is attached to the sea views afforded by high rise buildings. Also, land close to the sea commands high prices. These factors combine to provide an impetus for high rise building on land close to desirable sea locations. To many, high rise complexes appear to epitomise the archetypal MTTA complex (this is notwithstanding the typology advanced herein). The close proximity of distinct units of accommodation combined with their vertical relief appear as two factors pointing towards a multiple ownership structure in these high rise buildings.

The paper's review of factors driving MTTA's growth enlightens any consideration given to whether the apparent growth is likely to be sustained. Many of the factors identified point to the critically significant role played by developers in determining a tourist destination's physical landscape. As the factors all point towards developers having a strong motivation to establish MTTA complexes in preference to conventional single title properties, the question of whether MTTA's growth is likely to continue is best considered by investigating the likelihood of planning permit authorities giving developers a relatively free reign with respect to MTTA development. It would seem that research appraising the relative lobbying influence of developers, and planning authorities' attitudes to the particular issues arising in destinations with a high density of MTTA complexes, as well as their cultures with respect to the exercise of power and restraint, could help shed light on the likely continuation of MTTA growth.

The need for more MTTA research is profound. The range of avenues that this research may adopt is considerable. One useful research initiative could attempt to quantify the relative strength of different factors motivating the purchase of MTTAs. Further research is also required to ascertain developers' motives in building MTTA complexes. It is hoped the critique provided here can generate a level of research interest that is more commensurate with MTTA's standing as a distinct element in the suite of tourist accommodation options available. 


\section{References}

Aguilo, E., Alegre, J. and M. Sard, (2005) The Persistence of the Sun and Sand Tourism Model. Tourism Management, 26: 219-231.

Ardill, A., Everton-Moore, K., Fredline, E., Guilding, C. and J. Warnken, (2004) Community Titles Reforms in Queensland: A regulatory panacea for commercial, residential, and tourism stakeholders. The Queensland Lawyer, 25: 13-27.

Argawal, S., (2002) Restructuring Seaside Tourism: The Resort Lifecycle. Annals of Tourism Research, 29: 25-55.

Bramwell, B., (2004) Mass Tourism, Diversification and Sustainability in Southern Europe's Coastal Regions. In Coastal Mass Tourism: Diversification and Sustainable Development in Southern Europe, Bramwell, B., (ed.), pp. (1-31), Clevendon, Channel View.

Butler, R. W., (1980) The concept of a tourist area cycle of evolution: implications for management of resources. Canadian Geographer 24: 5-12.

Butler, R. W., (1991) Tourism, Environment, and Sustainable Development. Environmental Conservation 18: 201-209.

Cassidy, K. and C. Guilding, (2007). An exploratory investigation of tourist accommodation price setting in Australian strata titled properties. International Journal of Hospitality Management, 26: 277-292.

Coppock, J.T., (1977) Second Homes: Curse or Blessing? Oxford: Pergamon.

DBEDT (Department of Business, Economic Development and Tourism), Research and Economic Analysis Division, (2005) 2004 Visitor Plant Inventory, Honolulu: 2004 Annual. $\quad$ Retrieved 26. May 2006 from http://www.hawaii.gov/dbedt/sitemap.html

Everton-Moore, K., Ardill, A., Guilding, C. and J. Warnken, (2006) The Law of Strata Title in Australia: A Jurisdictional Stocktake. Australian Property Law Journal, 13: 1-35.

Field, H. M., (1995) Financial management implications of hotel management contracts: a UK perspective, In Accounting and Finance for the International Hospitality Industry, P. Harris, ed., pp. 261-277. London: Butterworth-Heinemann.

Gartner, W.C., (1987) Environmental impacts of recreational home developments. Annals of Tourism Research, 14: 38-57.

Guilding, C., (2003) Hotel owner / operator structures: implications for capital budgeting process. Management Accounting Research 14: 179-199. 
Guilding, C., Ardill, A., Fredline, E. and J. Warnken, (2005) An agency theory perspective on the owner / manager relationship in tourism-based condominiums. Tourism Management 26: 409-420.

Hall, C.M. and D.K. Müller, (2004) Tourism, Mobility and Second Homes. Clevedon, Channel View.

Harris, R., (2000) Industrializing English Law. Cambridge, University Press.

Hovey, M., (2002) Is timeshare ownership an investment product? Journal of Financial Services Marketing, 7(2): 141-160.

Irvine, C. and B. Cunningham, (1990) Second Homes. New York, Bantam Books.

Johns, N., and P. Lynch, (2007) The self-catering accommodation market: A review of electronic and other resources. International Journal of Hospitality Management, 26: 293-309.

Kaltenborn, B.P., (1997) Nature of place attachment: A study among recreation home owners in Southern Norway. Leisure Sciences 19: 175-189.

Klemm, M., (1996) Languedoc Roussillon: adapting the strategy. Tourism Management 17:133-147.

Müller, D.K and C.M.Hall, (2004) The Future of Second Home Tourism. In Tourism, Mobility and Second Homes, Hall, C.M. and D.K. Müller, (eds.), pp. (273 278) Clevedon, Channel View.

Nicod, P., Mungall. A. and J. Henwood, (2007) Self-catering accommodation in Switzerland. International Journal of Hospitality Management, 26: 244-262.

Pizam, A. (2006) Condominium hotels: A scorching hot lodging product. International Journal of Hospitality Management, 25(2): 167-169.

Smoke, A.M. and R. Burk, (2005) Assessing the impact of condotels in Waikiki. In Wings of Change in Tourism Research: Voyages of Inquiry and Discovery. Proceedings $4^{\text {th }}$ Annual Asia Pacific Forum for Graduate Studies in Tourism Research, Spears, D.L. (ed.) pp. (287-303), Manoa, University of Hawai’i.

Thomas, R. and D. Hind, (2007) The self-catering accommodation sector in Yorkshire, England. International Journal of Hospitality Management, 26: 328-335.

Valenzuela, M., (1998) Spain: From the Phenomenon of Mass Tourism to the Search for a More Diversified Model. In Tourism and Economic Development: European Experiences $3^{\text {rd }}$ Ed., Williams, A.M. and G. Shaw, (eds.), pp. (43-74), Chichester, John Wiley and Sons.

Warnken, J., Bradley, M., and C. Guilding, (2004) Exploring methods and practicalities of conducting sector-wide energy consumption accounting in the tourism accommodation industry. Ecological Economics 48:125-141. 
Warnken J., Russell, R and B. Faulkner, (2003) Condominium Developments in Maturing Destinations: Potentials and Problems for Long-Term Sustainability. Tourism Management 24:155-168.

Weaver, A., (2005) Spaces of containment and revenue capture: 'super-sized' cruise ships as mobile tourism enclaves. Tourism Geographies 7:165-184.

Williams, A.M., King, R., Warnes, A.M. and G. Paterson, (2000) Tourism and international retirement migration: New forms of an old relationship in southern Europe. Tourism Geographies 2:28-50.

Woods, R.H., (2001) Important issues for a growing timeshare industry. Cornell Hotel and Restaurant Administration Quarterly 42:71-81. 